\title{
Why Doesn't the Decriminalisation of Same-Sex Sexuality and Sex Work Ensure Rights? The Legality and Social Acceptance of Transgressive Sexualities in Urban Mozambique
}

\author{
Carolien J. Aantjes ${ }^{1} \mathbb{D} \cdot$ Khátia Munguambe $^{2,4}$ [D $\cdot$ Vasco Muchanga $^{2} \cdot$ Rehana Capurchande $^{3} \cdot$ Nana K. Poku $^{1}$
}

Accepted: 21 February 2021 / Published online: 20 March 2021

(c) The Author(s) 2021

\begin{abstract}
Background The dependence on the law to direct people's behaviour is known for its imperfections, yet it has become a mainstream response to social problems in modern day society. It is also the pathway through which internationally-recognised rights obligations, including sexual rights, are anticipated to diffuse across distinctly different societies. We studied the introduction of new legal standards in Mozambique, with an interest in their ability to promote the rights of lesbian, gay, bisexual, transgender, intersex (LGBTI) people and sex workers.

Methods Between 2019 and 2020, we conducted sixteen key informant interviews with jurists, policymakers, and civil society advocates at national level and seventy-eight interviews with opinion leaders from local communities in three urban sites situated across Northern, Central, and Southern Mozambique.

Results The new legal standards, in which same-sex sexuality and sex work are no longer criminalised, found little resonance with intersecting religious, sexual, gender, and socio-cultural norms. Whilst there was a consensus not to discriminate, sensitisation and rehabilitation of LGBTI people and sex workers were considered imperative. This stance, coupled with a continued presence of ambiguous language in and incongruences between legislative pieces, attenuates the country's commitment to internationally recognised rights obligations.

Conclusions In a context of weak civilian awareness and support, the legal reforms are not likely to make a profound positive impact on the lives of LGBTI people and sex workers. Policy action should extend beyond health and law enforcement institutions and draw in community leaders to mediate the social processes that undercut the universality of rights.
\end{abstract}

Keywords Law $\cdot$ Sexuality $\cdot$ Human rights $\cdot$ LGBTI $\cdot$ Sex work $\cdot$ Stigma $\cdot$ Morality

\section{Introduction}

The domestic codification of rights that affirm an individual's sexual autonomy tends to provoke deep normative disagreements. These arise from the different cultural meanings ascribed to sexuality and social rankings of what

Carolien J. Aantjes

aantjes.cj@gmail.com

1 Health Economics and HIV and AIDS Research Division, University of KwaZulu-Natal, Durban, South Africa

2 Faculty of Medicine, Community Health Department, Sexual and Reproductive Health Unit, Eduardo Mondlane University, Maputo, Mozambique

3 Faculty of Arts and Social Sciences, Department of Sociology, Eduardo Mondlane University, Maputo, Mozambique

4 Manhiça Health Research Centre , Maputo, Mozambique is considered good sexual behaviour and bad sexual behaviour (Lorber, 2018). Around the globe, religious ideologies have profoundly shaped these meanings and continue to be of influence-even in the most modern societies—on how societies understand and organise human sexuality into morally legitimate and illegitimate forms of behaviour (Altman, 2002; Ellingson \& Green, 2002). In distinguishing the deviances from socially prescribed sets of sexual desires and conducts, sexuality may become the object of oppression and have multiple and far-reaching consequences for individuals such as a disenfranchisement from health and social services, legal penalty, or social exclusion.

There is an extensive body of literature on the categorisation of same-sex sexual activity and sex work as "deviant" or "transgressive" sexualities and how these particular sexualities are frequently associated with immorality, disgust, health risk, and danger (Benoit et al., 2018; Richardson, 
2004; Smith \& Mac, 2018; Yep, 2003), together with other forms of vice such as street crime and drug use (Hough, 2004). The point of convergence between them seems to be rooted in a belief of moral decline if the act of paid sex or a homosexual identity is not being suppressed within society. Historically, laws have sought to preserve public order and culturally determined decency at the expense of individuals believed to threaten them, for example by condemning those involved in non-procreative or non-monogamous sexual activities (Hough, 2004), regardless of whether the sexual activity takes place among adults and is consensual. Criminal prohibitions against same-sex sexual activities in Europe, also typified as "crimes against nature" or "gross indecency," can be traced back as far as medieval times and reached other continents with the advent of colonisation (Gupta, 2008; Sable, 2010). The rise of Protestantism in the sixteenth century is believed to have a played a central role in the closure of brothels and the criminalisation of sex work on the European continent (Rublack, 2017). A new sexual morality, whereby all types of non-marital sexual intercourse were denounced, was promulgated and used to exert further power over, particularly female, sexuality — both at "home" and later overseas (Ellingson \& Green, 2002; Howell, 2000; Tamale, 2014).

The long-standing institutionalisation of repressive norms which have tainted sex workers and lesbians, gays, bisexual, transgender, and intersex $\left(\mathrm{LGBTI}^{1}\right)$ people around the world makes the fulfilment of rights for these groups deeply challenging. Whilst a growing number of individual States have been repealing their criminal laws and extending certain rights (such as the right to marriage), LGBTI people and sex workers continue to face various degrees of social disapproval and/or legal regulation (Drabble et al., 2020; Smith \& Mac, 2018). Moreover, there seems to be limited support for establishing a customary international law norm that would compel the still very sizable group of countries to remove references to same-sex sexual activity and sex work from their criminal laws and other laws or regulations used to intimidate or use force against LGBTI people and sex workers (Sable, 2010). As many as seventy countries currently penalise consensual same-sex sexual activity, out of which eleven prescribe a death penalty (Mendos, 2019). The sale, organisation, and/or the purchase of sex continue to be treated punitively in law and policy responses around the world, including in countries with liberal constitutions such as Sweden (Levy, 2014; Smith \& Mac, 2018; Vanwesenbeeck, 2017).

\footnotetext{
1 The authors refer in this paper to the commonly used acronym of LGBTI, but with an understanding that it encapsulates a group of people whose sexual interests, gender/sex dimensions, and goals for social recognition are different.
}

In the absence of an international law norm, supranational normative pressure to act remains but will be weighed against the political costs of enacting legislation that is incongruent with local social norms (Hafner-Burton \& Tsutsui, 2005; Poku \& Sundewall, 2018). As Stuntz (2000) said "if the law strays too far from the norms, the public will not respect the law," making it conceivable for political actors to fear they may alienate their constituency on such decisions (Stuntz, 2000). Laws that are considered to be in advance of social norms may face considerable implementation problems, starting from the very institutions that are expected to enact them (Baier, 2016). Liberal abortion laws have been a case in point for illustrating the shortcomings of the law in exercising legal authority in issue areas that are popularly considered to fall foul of a prevailing moral authority (Freeman \& Coast, 2019). The reliance on conscientious objection to maintain one's moral integrity and legitimately escape from providing safe abortion care has similarly been witnessed in countries legalising gay marriage (Wilson, 2012). Differing understandings of moral virtue and of moral duty can affect the integration of laws in society and, in the worst cases, would require enforcement, possibly sanctions, to compel citizens to obey the law. The rationale for calling on individual States to decriminalise same-sex sexual activity and sex work is not singularly premised on people's personal autonomy to determine when, with whom, and under what circumstances they engage in sexual activity. It interconnects with other fundamental rights, such as the right to equality and non-discrimination, to life, liberty and security, to be free from torture or degrading treatment, the right to privacy, to marry and to found a family, and the freedom of opinion and expression (UDHR, 1948; Miller et al., 2015). Evidence on the violations of these rights for LGBTI people and sex workers, resulting from their criminalised identity or activity, has been widely documented (De Lisio et al., 2019; Decker et al., 2015; Herek, 2011; Knauer, 2012; Poku et al., 2017; Scorgie et al., 2013).

This paper discusses the case of Mozambique in Southern Africa where, in a time span of 15 years, important modifications were made to the country's legal framework to further integrate the core human rights principles of equality and non-discrimination. Our particular interest was in the actions taken to dismantle any legal distinctions between citizens based on their sexual identity or sexual activity which would infringe these principles, and to protect against rights violations. With this purpose in mind, we concentrated on groups of citizens in Mozambique that are distinctively different from each other but who, until recently, shared the commonality of engaging in illicit sexual activities. Key legislative changes included the removal of articles referring to same-sex sexual activity and sex work as crimes and the insertion of sexual orientation as one of the prohibited grounds for 
discrimination in the workplace (Penal Code 35/2014; Labour Law 23/2007). Apart from legislative action, Mozambique's former President Joaquim Chissano called on African leaders to end all forms of discrimination by articulating in an open letter: "We can no longer afford to discriminate against people on the basis of age, sex, ethnicity, migrant status, sexual orientation and gender identity, or any other basis - we need to unleash the full potential of everyone. As an African who has been around a long time, I understand the resistance to these ideas. But I can also step back and see that the larger course of human history, especially of the past century or so, is one of expanding human rights and freedoms. African leaders should be at the helm of this, and not hold back. Not at this critical moment." (Chissano, 2014).

The reform of Mozambique's criminal law and Chissano's appeal stood out as it occurred at a time when a number of other African countries decided to further harshen their laws on same-sex sexuality (Gerber, 2014; Namwase, 2017). Repressive laws are also in place in the countries surrounding Mozambique, with five out of six countries criminalising same-sex sexual activity (Mendos, 2019), and four countries criminalising sex work (Mgbako, 2016). To date, there has been limited research on how Mozambican citizens view same-sex sexuality and sex work, apart from a multinational population-based survey which reports considerably higher tolerance levels towards same-sex sexuality in Mozambique compared with most other countries on the African continent (Dulani et al., 2016). A comparative analysis between Portuguese and British colonial rule provides some further insight into why tolerance levels may be higher in Mozambique (da Costa Santos \& Waites, 2019). Scholars suggest that this may relate to the relatively late initiation of legal repression on same-sex sexuality by the Portuguese as compared with the British, and which primarily seemed to be instituted to keep the sexual behaviour of white European males living in Mozambique in check. Findings from a few smaller-scale qualitative studies suggest the presence of contending views, following experiences of social stigma and discriminatory acts reported by LGBTI people, and also by sex workers in Mozambique (Gamariel et al., 2020; Hendriks \& Rácz, 2016; Centro de Direitos Humanos, 2017). This paper explores the current legal framework and the views and positions on the affirmation of LGBTI and sex worker rights in the law among legal experts, policy makers, civil society pressure groups, and community opinion leaders, with the purpose of critically reflecting on the capacity of the law to exert influence over socially contentious issues and the processes through which certain groups in society are set apart based on their sexual identity or sexual activity.

\section{Methods}

\section{Study Setting}

The study was carried out between February 2019 and February 2020 in urban, sub-urban, and peri-urban areas of three purposively selected cities of Mozambique. Whilst Maputo and Nampula were selected to represent the South and Northern regions respectively, Beira was originally chosen as the site in the Central region, but due to the consequences of the Idai natural disaster, the site was replaced by the city of Quelimane in the same region. The three study sites were selected to capture, to the extent possible, the geopolitical and cultural diversity of the country. Site selection was also informed by two HIV-focused biological behavioural studies, demonstrating a large presence of female sex workers and men who have sex with men in these locales (do Rosário Augusto, 2016; Nalá et al., 2015). This presence and the (potential) visibility of the groups in the community were considered important in light of our study aim. Most cities in Mozambique are organised as municipalities, divided into Municipal Districts (MD) or Administrative Posts (AP), which in turn are divided into neighbourhoods (in Portuguese: bairros) and neighbourhoods into neighbourhood blocks (quarteirões). Maputo City is located at the Southern tip of the country. Administratively, it is simultaneously a province and a municipality, covering a total area of $346.8 \mathrm{~km}^{2}$ and a population of 1,094,315 inhabitants (INE, 2019). The municipality comprises seven Municipal Districts. Typical for a capital city, Maputo has a confluence of different ethnicities but has largely been dominated by the Ronga and Changana ethnic groups, with Catholicism as the main religion. Nampula is the capital city of Nampula Province and is classified as the third largest in the country, after Maputo and Matola. It has a population of 743,125 inhabitants, circumscribed in an area of $330 \mathrm{~km}^{2}$ (INE, 2019, and six Municipal Administrative Posts). The Macua are the main ethnic group, and Islam is the dominant religion throughout the entire Nampula province. Quelimane is the capital of Zambézia province. The city comprises simultaneously a municipality (with an elected local government) and a district, which administers the powers of the central government, both covering the same geographical area. Quelimane has an approximate area of $117 \mathrm{~km}^{2}$, a population of 193,343 inhabitants (INE, 2019), and is administratively divided into four Municipal Administrative Posts. The Lomwé and Chuabo are the main ethnic groups in the city, and the main religion is Christian, predominantly Catholic.

\section{Study Participants and Recruitment}

We conducted 16 semi-structured interviews with key informants at the central level in Maputo City, who were 
identified as knowledgeable on issues related to the legal and social position of LGBTI people and sex workers and familiar with the law reforms either as legal experts, policy-makers, program managers (governmental and nongovernmental), or as civil society advocates. Additionally, we conducted 78 semi-structured interviews with individuals who fulfilled a leadership role in selected neighbourhoods of Maputo, Nampula, and Quelimane cities for their knowledge of and influence on their respective communities, whom we denominated local opinion leaders. For a description of the sample, see Table 1.

Key informants at the central level were identified and recruited through purposive sampling and snowballing, based on the researchers' previous knowledge of institutions and individuals directly involved in activities related to the law reforms and of those who used these specific laws as an instrument of their work in defence of human rights in a court room or in the implementation of health and rights policies and programmes in the country. Opinion leaders were identified and recruited through purposive sampling and snowballing, combining different techniques as described in the literature (Weimann et al., 2007; Tsimitri et al., 2015) and using the following criteria: male or female above 18 years of age; neighbourhood residence for $\geq 10$ years; representative of a local entity or group, with an active role in the mobilisation of or engagement with residents in neighbourhood activities; known by neighbourhood residents and through their roles recognised as influential individuals in the neighbourhood; and a mental ability and willingness to participate in the study. Before entry into the neighbourhood, the researchers compiled a list of potential participants, based on the researchers' in-depth knowledge of community structures and structures of influence in the country as well as on suggestions from LGBTI and sex worker civil society pressure groups. This provisional list was verified at neighbourhood level, and nominations for local opinion leaders were obtained from the AP/ MD headquarter chief as well as from 3 to 5 ordinary residents approached on the street in each neighbourhood. Apart from administrative and political leaders, an amalgamation of religious leaders (predominantly the top local leaders of churches and mosques), women and youth group leaders in each of these neighbourhoods were nominated through this process, as well as community judges, régulos (which are traditional rulers or regulators in a parallel chiefdom system) and community-level health actors, such as traditional healers, health promotors (who conduct most health promotion activities in the neighbourhoods), and conselheiras (who have close contact with the youth in the context of initiation rites and preparation for adulthood).

Participants were drawn from eighteen different neighbourhoods in Maputo, Nampula, and Quelimane, which were selected using a stratified purposeful sampling approach. In the identification and selection of APs/MDs in each city, the researchers took into account the heterogeneity of the urban population in terms of socio-economic standing, access to services and basic infrastructure, population density, and mobility, using the available documentation on each site. This resulted in a sample of three APs/MDs per city and two neighbourhoods per AP/MD (i.e. 6 neighbourhoods per city), representing a fair mix of different socio-economic strata and residential area characteristics.
Table 1 Sample size per site and participant group, including gender and role characteristics

\begin{tabular}{|c|c|c|c|c|c|c|}
\hline & Male & Female & Maputo & Nampula & Quelimane & Total \\
\hline \multicolumn{7}{|l|}{ Key informants $(n=16)$} \\
\hline Government policy maker & 1 & 3 & 4 & 0 & 0 & 4 \\
\hline Jurist & 0 & 2 & 2 & 0 & 0 & 2 \\
\hline Academic & 2 & 0 & 2 & 0 & 0 & 2 \\
\hline Civil society activist & 3 & 2 & 5 & 0 & 0 & 5 \\
\hline INGO programme manager & 1 & 2 & 3 & 0 & 0 & 3 \\
\hline \multicolumn{7}{|l|}{ Opinion leaders $(n=78)$} \\
\hline $\begin{array}{l}\text { Head of an administrative post / } \\
\text { municipal district }\end{array}$ & 7 & 1 & 2 & 3 & 3 & 8 \\
\hline Neighbourhood secretary & 22 & 2 & 5 & 12 & 7 & 24 \\
\hline Head of a neighbourhood block & 5 & 3 & 5 & 3 & 0 & 8 \\
\hline Religious leaders & 12 & 1 & 4 & 5 & 4 & 13 \\
\hline Traditional authority (régulo) & 0 & 1 & 0 & 0 & 1 & 1 \\
\hline Youth leader & 8 & 5 & 3 & 4 & 6 & 13 \\
\hline Women's leader & 0 & 2 & 0 & 1 & 1 & 2 \\
\hline $\begin{array}{l}\text { Health promotor/ counsellor (con- } \\
\text { selheira)/traditional healer }\end{array}$ & 2 & 6 & 2 & 4 & 2 & 8 \\
\hline Community judge & 1 & 0 & 0 & 1 & 0 & 1 \\
\hline Total participants & 64 & 30 & 37 & 33 & 24 & 94 \\
\hline
\end{tabular}




\section{Data Collection Procedures}

All interviews were conducted in Portuguese, except one interview which was conducted in the local language Changana. All except two interviews were audio recorded with the permission of the participants and transcribed verbatim in Portuguese by a trained transcriber. The two unrecorded interviews with key informants were captured through detailed annotations of what was discussed, which were completed immediately after the interviews. The key informant interviews were guided by an interview guide (see supplementary file A) consisting of semi-structured questions exploring the informants' understanding of the principles of equality and non-discrimination and how these principles are promoted in law, policy and practice, their in-depth knowledge of particular pieces of legislation (i.e. the constitution, labour law, and penal code), and linked reform processes, as well as perceptions on the dissemination and implementation of these laws. A desk review of laws, policies and guidelines, published studies, grey literature, dissertations, and social media and media coverage on the legal and social position of LGBTI people and sex workers in the country ran concurrently with these interviews. The opinion leader interviews were semistructured, following an interview guide (see supplementary file B) in which their understanding of the principles of equality and non-discrimination were explored, as well as their knowledge of the constitution, labour law and penal code (including the recent reform of this code), and views on LGBTI people and sex workers and how the leaders and members of the neighbourhood in which they resided interacted with LGBTI people and sex workers. Interviews lasted between $30 \mathrm{~min}$ and $2 \mathrm{~h}$. Interviews were conducted face-to-face and administered by one to two researchers at a location of the participant's preference. In the majority of interviews, the participants' preference was to use their own work premises.

\section{Data Analysis}

The study took a thematic approach to the analysis of the data, as laid out by Huberman and Miles (1994). Nvivo 12 software was used to systematically organise and analyse the transcripts that were generated from the interviews. Opinion and key informant transcripts were analysed in two separate datasets. In both datasets, the researchers used deductive and inductive coding, whereby the initial coding frameworks were developed based on the study objectives, research questions, and interview guides during team consensus meetings. Next, codes and subcodes were uploaded and the coding process was piloted for a select number of transcripts within the software programme in order to assess the stability of the coding frameworks. During this process, some existing codes were adjusted (in terms of ensuring that the chosen names were aligned with the participants' ideas) and new codes (emerging themes) were created and added, either as main or subcodes. Once the frameworks proved firm, i.e. the speed at which new codes were created decreased or ceased, the remainder of interviews were uploaded for coding. The first author assessed the coding for consistency and for errors at several intervals of the coding process. After this, coding queries were created, either by selecting specific single codes or combinations of codes, in response to initial research questions and newly emerging questions with the purpose of building up the analysis.

\section{Results}

The "Results" section is divided into five subheadings, starting with a brief overview of our desk review findings on the changes in key pieces of legislation since independence that touch the lives of LGBTI people and sex workers. These changes are subsequently analysed, using the insights from our primary data, for stakeholder involvement in and perceived robustness of the changes in protecting the rights of LGBTI people and sex workers, followed by an analysis of the public awareness of the legislative changes and their perceived legitimacy, which lie at the heart of integrating new laws in society.

\section{Legislative Changes}

Codification of the equality principle started upon promulgation of the constitution, right after independence from Portuguese rule, in 1975. Accentuated by a socialist political regime and interventionist economy at the time, the law's conception of equality was largely economic and sought to distribute wealth more evenly across the populace. Constitutional amendments took place at several junctures during the civil war, of which the 1990 revision is important to note not only for its political and economic turn-enacting a multi-party democracy and a market economy-but also for its explicit provision to punish any acts creating division or situations of privilege or discrimination between citizens (art. 69), and its enshrinement of the individual human right to life (art. 70) and privacy (art. 71). The first major post-war revision of the constitution in 2004 expanded the grounds of fundamental civic rights, duties, and freedoms with political affiliation in article 35 . This article guarantees that all citizens are equal before the law "regardless of their colour, race, sex, ethnic origin, place of birth, religion, level of education, social position, the marital status of their parents, their profession, or their political 
preference." ${ }^{2}$ Sex equality, which was addressed in a separate article of the constitution, was understood to be between a man and a woman and to cut across all spheres of political, economic, cultural, and social life (art. 36). An extensive reform process ensued and led to the adoption of several pieces of legislation, including the family law (10/2004) and the labour law (23/2007). There was also an attempt to review and reform the (1886) penal code, which had been amended by the Portuguese in 1954 to include the criminalisation of individuals habitually practicing "vícios contra a natureza" (vices against nature), alongside vagrancy and mendicancy, whilst Mozambique was still under their rule, but this process stalled in the 2009 elections.

During the drafting of the labour law, sexual orientation surfaced as one of the three grounds for non-discrimination in employment. Article 4 states that the labour law "shall be interpreted and applied in accordance with, among other principles, the principle of the right to work, of employment stability and job stability, of change in circumstances and of non-discrimination on grounds of sexual orientation, race or HIV/AIDS." Furthermore, the law explicitly mentions the right to privacy in the access to and dissemination of matters relating to the private and personal lives of employees, including their sex lives (art. 5). According to key informants, the insertion of sexual orientation in this legal document passed without contestation from the constitutional council. Nonetheless, subsequent revisions of the constitution, as well as other key legislative pieces, did not set forth this distinction of sexual orientation as an additional ground for equality, non-discrimination, and protection. In 2008, further legal attention was given to the employment of minors under the age of eighteen in the sex industry, prohibiting the use, recruitment or offering children for sex work, and the production of pornographic material or performances through the enactment of a law on human trafficking (6/2008, art. 11-14) and a law on the promotion and protection of children's rights (7/2008, art. 63).

The penal code reform regained momentum when the government assigned the review and reform of the code to a parliamentary commission of constitutional, human rights, and legality matters by the end of 2010. In the revised code, discrimination became a crime, penalising those who abuse others through the use of expressions, reflections of prejudices about race or colour, religion, age, disability, disease,

\footnotetext{
${ }^{2}$ Mozambique also ratified the International Covenant on Civil and Political Rights (1966) and the African Charter on Human and Peoples' rights (1981) which guarantee the right to equality and the right to be free from discrimination. The rights in the African Charter are applicable to everyone without distinction. The Covenant's reference to sex as a ground for non-discrimination may be interpreted to include sexual orientation (communication 941/2000).
}

social status, ethnicity or nationality, and where intended to offend the victim's honour and self-esteem (35/2014, art. 243). Further key revisions to the code included the removal of ambiguous language that provided for security measures, such as a 3-year confinement in a labour camp for second-time offenders (art. 70 §), against individuals engaging in practices of "vícios contra a natureza" (art. $71 ; 4$ ) and to prostitutes causing public scandal or continually disobeying police orders ("às prostitutas que sejam causa de escândalo público ou desobedeçam continuadamente às prescrições policiais" (art. 71;5). There has not been an active enforcement of these two articles post-independence among members of the LGBTI community (Da Costa Santos \& Waites, 2019; the Other Foundation, 2017), but arrests have been reported by sex workers and the non-governmental organisations who work closely with them (Hendriks \& Rácz, 2016). In the revised penal code, the promotion of sex work remains a crime (art. 227) and all activities involving minors in sex work are penalised on grounds of sexual abuse or exploitation.

\section{Inclusivity of the Reform Process}

The nature, pathway, and length of law reform processes in Mozambique can diverge quite considerably, but the initiation of such processes can only formally be proposed by five entities and only Parliament approves laws and decree-laws. These five entities are as follows: (i) Members of Parliament, (ii) Parliamentary Benches, (iii) Parliamentary Committees, (iv) President of the Republic, or (v) Members of the Government. Law reform processes proposed by Parliament are led by a Parliament commission, and those proposed by the Executive are led by the government Ministry that is considered responsible for the "subject matter." In theory, citizens can influence the initiation of the process by putting pressure or lobbying for a revision or reformulation of a law or policy on a subject that stirs the society across various social, political, economic, and cultural dimensions. During the reform process, citizen groups can comment on draft bills and/or be invited to participate in parliament commission meetings or in the drafting of Ministry-led law proposals. The constitutional council holds the authority to veto any law that is deemed unconstitutional.

The constitution of 2004 is also called the "consensus constitution" as it engaged all in Parliament represented political parties in its articulation and included a broad public consultative process. The development of the labour law seemed to have occurred more quietly and exclusively. The initiative to insert sexual orientation into this particular law, according to informants, was believed to originate from external advisors, contracted by donors to support its development, and not by any political party or by a civil society-led lobby as the country's main LGBT organisation, 
LAMBDA, had only just been formed. This may partly explain the absence of further references to sexual orientation in legislation passed after the 2007 labour law.

Donors paid for the revision of the Labour Law. There were several things that needed to be addressed: the question of maternity [leave], the question of...there were various elements, probably this person that paid also demanded this question.... Key informant, government policymaker

Between 2010 and 2014, a wide range of civil rights movements closely followed and tried to intervene in the penal code reform process. They united in a coalition and jointly pushed multiple human rights issues, among others calling for the inclusion of provisions to criminalise sexual offences such as marital rape, and the decriminalisation of abortion and consensual same-sex sexual acts. In reconstructing what had led to the decision to remove the two articles applying security measures to acts against nature in a second version of the draft bill, LGBT activists were hesitant to attribute this change to the direct influence of civil society based on their own experiences during the reform.

There was not a big discussion with civil society... proposals were drafted by civil society and us to discuss the issue of women's rights, children's rights, all human rights issues, but not all things happened... we lobbied but not all things happened... at least from the penal code those two articles that criminalized homosexuality were removed, but we were not able to influence. Key informant, civil society pressure group LGBT rights

Legal expert informants affirmed that the removal of these articles from the penal code had, first and foremost, been instigated by the need to rid this particular law from outdated articles.

During the penal code revision, the removal of these articles from the code was extremely positive, not as a response nor as a reaction to this movement but precisely because of the subjectivity of those articles [...] this subjectivity could make anybody use, even use diabolic arguments, to really manage to prove that being a LGB is against nature. Key informant, government policymaker

This "mismatch" between the former code and the political, social, cultural, and economic reality in modern-day Mozambique is also reiterated in the preamble of the penal code $(35 / 2014, \mathrm{p} 1)$. Whilst important progress was made in aligning the penal code to the revised constitution and various international treaties, respondents who had been part of the civil society coalition also remarked on the limited inclusivity of the reform process. For example, the consultation meetings with the Commission in charge of the reform had reportedly been restricted to a few hours in each Provincial capital and thus gave very limited space for a constructive public engagement on the proposed draft bill, beyond the submission of written suggestions. As discussed in further detail in the next section, pleas for a further preciseness of language in the penal code and alignment between the code and other legislation proved unsuccessful.

After all our work, and when the final proposal came out, we felt that what had been our contributions that we put in the petition meeting, were not there. We went to the streets to make noise and it sure had international impact. On the week scheduled for approval of the penal code we sat at Parliament making a noise until [Name of the Parliament president] received us. We marched and went there with our document and said: look we had clandestine access to the final proposal, nobody shared with us the official copy about to be approved, it is just because someone from the benches said girls, wake up! We were shocked for example about the "penalization" of raping an underage child which simply forced the perpetrator to marry the child!Key informant, civil society pressure group women's rights

\section{Perceived Robustness of the Legislative Changes in the Protection of Rights}

We posed the question whether the combination of changes provides a sufficient legal basis for the protection of sex worker and LGBTI rights in Mozambique. The legal experts that we interviewed were of the opinion that the current legal framework would suffice, as it grants constitutional rights to all citizens and protects against discrimination, defamation, physical, and psychological violence through the general provisions in the penal code. They were (almost unanimously) of the opinion that anti-discrimination laws, specifically protecting these two groups, would not be necessary. Sex worker organisations and international organisations working with sex workers in the country disagreed and argued that additional measures are needed for protecting sex workers against violence from clients and the police. Members of the LGBT movement also disagreed with these experts and argued that in the current social context, rights should be further protected through an explicit adoption of gender identity and sexual orientation as punishable discriminatory grounds in article 243 of the penal code as well as their affirmation in the grounds for equality in article 35 of the constitution. Furthermore, they argued that ordinary law has been used before to authorise affirmative action in the case of specific groups of individuals, for example to protect HIV positive employees or women from domestic violence 
(19/2014 and 29/2009 respectively). Recommendations from the international community to further secure rights protection for LGBTI during the Universal Periodic Reviews in 2011 (p. 23) and 2016 (p. 23) have not been implemented to date (Human Rights Council, 2011, 2016).

Uneasiness with the protective value of the current legal framework for sex workers stems from the impreciseness of the penal code revision in removing all of the language that could possibly conflate with sex work and the law $(35 / 2014)$. For example, article 225 was retained in the code's section on crimes against sexual freedom. In this article, "ultraje público ao pudor" (public outrage against decency) is penalised with an imprisonment up to 6 months and a fine. However "pudor" remains undefined. Similarly, article 241 penalises crimes against honour based on "ultraje à moral pública" (public outrage against morality) with imprisonment up to three months and a fine, without giving a further specification. An additional point is that some older laws are still being enforced as if the decriminalisation never occurred, and directly affect the LGBT and sex worker-led pressure groups. Following the use of a clause on moral order in the Associations law, the groups have had difficulties with obtaining a legitimate status as organisational entities from the Registrar. Article 1 of the Associations law states that: "not-for-profit associations can be constituted, as long as their purpose is in conformity with the constitutional principles which are grounded in the moral, economic and social order of the country and which do not offend the rights of third parties or the public good" (8/1991). Different strategies were observed for overcoming this legal barrier. The main sex worker-led pressure groups in Mozambique, Tiyana Vavasate, UnGaGodoli, and ABEVAMO all opted for less explicit organisational objectives and successfully obtained registration as associations of vulnerable women. LAMBDA pursued their registration as an LGBT rights organisation and through the Ombudsman, took the case to the Constitutional Court in 2017. This court ruled that the use of this clause had been unconstitutional, but despite this decision, LAMBDA has still not received a registration.

The legality of same-sex sexual activity and sex work is not supported either through other laws, in which important individual rights and entitlements have been laid down. For example, there is no legal inclusion of sex workers in laws pertaining to employment rights, with a labour law that primarily protects and defends the rights of workers employed by a registered and legally recognised institution. Complementary legislation exists for a number of professions in the informal sector, such as domestic workers, work-at-home employees or artists, but not for adult sex workers. As sex work remains an unrecognised profession, work-related rights and entitlements do not apply to this group.
Sex work is not a crime; it is not legal but it is not illegal either. For example, in the labour law, it is not even defended. [The law is for] people who are linked to an institution that have a job with characteristics X, Y Z, but we do not talk about this question, sex work is not conceived as work in a way that makes it appear in the law. Key informant, programme manager international non-governmental organisation

The right to constitute a family through marriage excludes individuals in same-sex relationships as the family law recognises male-female unions only (10/2004). As the law considers marriages contracted by people from the same sex as "legally non-existent," marriage-related rights of joint adoption and custody of children do not apply. Interestingly, some of the interviewed legal experts and academics believed that the current legal framework would be robust enough to litigate on these rights, if necessary, in combination with international law.

The conservatory [other name for civil registrar] would celebrate [same sex] marriage because they can make a cocktail of the family law, labour law, constitution... fundamental rights that includes the right to equality and freedom. Fundamental rights are not only those that are listed in the constitution, provided that the violation of the right in question does not violate the dignity of the human person. If there are gaps in the law, they can apply the African charter and the universal declaration of human rights. Key informant, Academic Institution

Beyond the legislative action, a number of public policies have been drawn up with specific recognition of LGBTI and sex workers' rights to health and justice as key populations in the HIV response. Country health sector and HIV/AIDS plans and guidelines focus on equity in access to and the provision of non-discriminatory health services (CNCS, 2015; Ministry of Health, 2015), whilst instruments from the Ministry of Home Affairs, such as a Police trainer's handbook for key populations and a procedures guide for key populations, were developed to support LGBTI people and sex workers in reporting violence to this institution and in seeking redress (Ministry of Home Affairs, Pathfinder, \& Bridging the Gaps, 2018). Policy initiatives such as described above are financially supported through the Global Fund to Fight AIDS, $\mathrm{TB}$, and Malaria and other international donors working on HIV and with key populations.

From our analysis of the current legal framework, we can deduce that the country has enacted very little legislation in support of LGBTI people and sex workers beyond their rights and entitlements as citizens of Mozambique. The revisions to the penal code were significant, but the current silence of the legal framework (i.e. it neither 
criminalises nor legitimises same-sex sexual activity and sex work), and the use of language and incongruences between different pieces of legislation attenuate the ability of LGBTI people and sex workers to counter infringements of their rights based on their particular identity or behaviour. The only law that has begun to clearly confer relevant rights and entitlements and which directly speaks to the priority concerns of LGBTI people-freedom to express their sexual orientation, their gender identity, and the right to non-discrimination and equality on the basis of sexual orientation and gender identity-is the labour law. Other protective measures in the form of public policy primarily sensitise and guide public servant interactions with these groups and are not currently directed towards the community where strong sentiments exist, as we will discuss in the next section.

\section{Awareness of the Legislative Changes}

We found no evidence to suggest that the government of Mozambique made large-scale public announcements of the changes made to its criminal and labour law. Both laws were published in the Official Gazette of the government (Boletim da República de Moçambique) but were not supported by public awareness-raising campaigns, as one key informant recalled:

For example, the Family law, there was some noise out there to better disseminate it etcetera, but the other laws they are not seen present in the discussion outside the legislators' environment. Key informant, civil society pressure group LGBT rights

However, the penal code revisions were celebrated via social media channels and received international media attention, with a primary focus on the significance of the changes for the LGBTI community.

Homosexuality will cease to be a crime in Mozambique (source: www.vocativ.com/197378/mozambiques-antigay-law-is-history/index.html June, 12015 ).

Mozambique becomes 21st African nation to legalize same-sex relations (source: www.globalgayz.com/gaymozambique/159/ June, 2015)

Law comes into effect today! From today, Mozambique is a better place to live! (source: Facebook post, June, 29 2015, dezanove.pt/homossexualidade-vai-deixarde-ser-794419)

Mozambique decriminalises gay and lesbian relationships (source: www.bbc.com/news/world-africa33342963, July, 12015 )

Respondent interviews exposed considerable knowledge gaps on the legislative changes, also among informants with privileged access to information such as academics and senior government officials. A majority of opinion leaders expressed no awareness of the removal of articles penalising same-sex sexual activity and sex work from the penal code and the inclusion of sexual orientation in the labour law, including those leaders who represent the government at the local level. Two neighbourhood secretaries from Nampula in Northern Mozambique explained:

The State still has a lot to do so that the laws are known. I want to know about this law: what does it say or where I can have more information about this law on homosexuals and women, also these women, sex worker women. Opinion leader, neighbourhood secretary 1 Nampula.

The community is not responding to the law because the law stays there [referring to the capital of Maputo]. There they make the law and the people do not disclose the law here in the communities. Opinion leader, neighbourhood secretary 2 Nampula.

One other neighbourhood secretary added to this the concern that the dissemination of new legislation through the government Gazette is in Portuguese only and thus excludes readership in the community.

A fair understanding of the constitution and the labour law could be observed among leaders, as well as how these two pieces of legislation embodied the principles of equality and non-discrimination for them. They consistently compared the constitution to the Holy Bible or the Quran as the overarching directive for the populace, for example by referencing how all human beings are equal in the eyes of God/Allah and equal before the law. Among elderly leaders, understandings of equality intersected with the vision of unity as articulated by late President Samora Machel in an effort to dismantle racial, ethnic, and class hierarchies. With regard to equal employment opportunities and remuneration, a strong sense of fairness emerged from the interviews across human differences, including those of a different sexual orientation.

If it is a salary, it doesn't matter [if the worker is male or female, or if one is gay] (...) Yes, everyone is equal, all are workers from the same infrastructure [foundation]. Opinion leader, neighbourhood secretary 1 Quelimane.

Like I already said, it is her private life. If she comes here to do the same job with me, we will have to receive the same thing because we are doing work here, at night her place is.. you know, she is the only one that knows. Opinion leader, youth leader 1 Quelimane 


\section{Perceived Legitimacy of the Legislative Changes}

We found a consensus among leaders on the right to nondiscrimination for all citizens, including for LGBTI people and sex workers who were regarded as rights-holders to the extent that this entailed socio-economic rights, such as food, shelter, employment, or social protection.

All people must be protected regardless of what the person does. I will not just [passively] watch my neighbour, because she is a sex worker someone is assaulting her and I am indifferent. She is a person, when she says "help!" she is a person...because she is in a situation that needs help, her work is her work, it is true that it [her work] does not please anybody, but it is her job, but now someone's life is someone's life. Opinion leader, head of a community block Maputo

However, in many of the interviews, a tension was apparent between the agreement on non-discrimination for all citizens and the articulation of a normative social practice in which same-sex sexuality and sex work were viewed as inappropriate and transgressive sexual activities. This led leaders to openly contest the government's decision to reform the penal code, whilst others supported the law but raised concerns around its dissemination and public acceptance. According to one of the leaders who supported the law reform, the unawareness of the legislative change, together with a widely held view in his city Nampula that same-sex sexuality was an abnormal occurrence, impeded its compliance. He clarified this as follows:

I think it is a good law, yes, everyone really has the same right, none should be discriminated against (...) but now that they are ready to implement this law, it is complicated (...) but that's an orientation, a sexual orientation that people have it, so it is really good, they've done well, the government is making a lot of effort, but the law isn't here at the base, it is not getting there properly, here continues discrimination (...) it is not being spread (...) here in the communities. and, In my case I accept if he [my son] says: ... with John I will get married, I will join John [in marriage] and this and that... for me it is normal. I do not know if for my family it is also [normal]. I accept, but my family, uncles, brothers, nephews, no, this is abnormal. It is really complicated here in the community. Opinion leader, neighbourhood secretary 1 Nampula

The three most common and interlinked arguments against the reform were the deviance of such law from religious scriptures, its encouragement to disrupting social order, and alienation from prevailing socio-cultural norms. Religious worldviews were applied by both religious and non-religious leaders to interpret the new legal norms and subsequently deem them as illegitimate.

Because God said man and a woman, and did not say man between man. Opinion leader, religious leader 1 Nampula.

Because God created something, masculine is masculine and feminine is feminine. Now imagine if God had made only men, how would this world grow? How? Because a human here has a mission to make the world grow, to be able to give birth. Opinion leader, neighbourhood secretary 1 Maputo

I look at sex as one of the elements that compose a man, although its function may be to reproduce, but that they may have one and only one man or woman, and not as an object to be distributed in any way, this job [sex] should be done with so much respect. Opinion leader, neighbourhood secretary 3 Nampula

By removing the articles from the penal code, leaders argued that the Biblical/Quranic crime of choosing the evil over the good will not be undone. Some went further by stating that in these instances, the divine law would override the authority of - what they articulated as - the "man-made law" and that if in breach, members would face rejection or expulsion from the faith community.

The thing to say it is no longer a crime but spiritually that is a sin; the Bible calls it sin [same-sex sexuality]. Opinion leader, neighbourhood secretary 4 Nampula. Participant: "In church, we don't admit [sex workers]. When she comes, she must confess and leave it [her practice], otherwise she is not admitted". Researcher: "What if that is her survival source, and she only wants to come to pray? Do you have a way of just letting her pray?" Participant: "If she comes to pray, she will be admitted, but there are some requisites (...) in order for her prayers, for her life to be protected in the hands of the Lord, then she must confess, and then we will pray for her, and her ways of survival will change". Opinion leader, religious leader Quelimane

Further portrayals of evils and their implications for society demonstrated the fear of a deterioration of religious values and loss of morale in the country if this law would be implemented. In some interviews, for example, same-sex sexual activity was conflated with different forms of petty crime, such as thievery or drug abuse, to even violent criminal acts, such as murder. At this juncture, leaders critiqued the role of the State in condoning behaviours which strayed from the "righteous path."

If we go in the Bible itself it is against the doctrine of God, not of man but the doctrine of God [...] if the government admits these things is when we are lament- 
ing. Why are we to grieve with these men who have sex with their own brothers. Why we are fed up to cry day by day for criminals who kill, murder, do everything the community is not in favor of and in Maputo it has been so, not only in Maputo, almost all of Mozambique now. If it were that the law of Samora, our President Samora, existed until today there would be no thieves ${ }^{3}$. Opinion leader, religious leader 2 Nampula.

Moreover, and viewed as a direct result of legalising sex work, the State was held responsible for facilitating the further spread of HIV, making their efforts to prevent this disease futile. Notwithstanding an awareness of povertydriven sex work in their neighbourhoods, leaders were of the view that the long-term health risks should forewarn the individual to consider other means of subsistence.

Transgression from the norm by LGBTI people and sex workers was also argued on the basis of a cultural heritage which had neither sex work or same-sex sexual activity.

Sex work of course is not a work of an African, it is not the work of a Macua. In my case it is a job that we are learning from other continents, we learnt [it] in this way but the original African, [among the] Macua specifically, there has never been this human work of sex. Opinion leader, neighbourhood secretary 3 Nampula. In my heart, in my innermost these people are people of bad faith, what would be better would be [for] him to accept to be reconciled, abandoning what he is doing. He should also be ashamed that in Mozambique there are homosexuals, [despite this being] a new country where all things could be new [they should be] well moderated. Opinion leader, community judge Nampula.

The belief, also heard elsewhere in the region, that these behaviours were not indigenous but imported was expressed through a lexicon inviting of remedial action, such as "maluco" in Portuguese (crazy) or "patetas" in Portuguese (goofy) for transwomen. Encounters between the leaders and LGBTI people appeared to be very limited; thus, their presence in the social imaginaries of leaders remained to some extent hypothetical. Also, sex workers were mostly believed to be operating from neighbourhoods other than one's own.

Well, these people, whether they exist or not, may exist, but it is difficult to discover that this one is a lesbian, this one is homosexual, it is very difficult to discover this. Yes, so I do not know if there is anything, [it is] different

\footnotetext{
${ }^{3}$ During this term, in the year 1983, President Machel ordered "Operation production" to fight crime, prostitution, vagrancy, and urban chaos and expelled all those who were deemed undesirable and unproductive from the cities (particularly from the capital).
}

from pinpointing the drug addicts, a drug addict is easy to discover but these homosexuals, and also lesbian women. it's difficult. Opinion leader, religious leader 1 Maputo.

Among youth leaders, which in comparison were more familiar with LGBTI people and sex workers in their surroundings or through watching television shows, we noted an uneasiness with accepting the new legal norms. Their reservations similarly stemmed from intersecting religious, gender, and socio-cultural norms as well as health concerns.

It is not good because if the law said that there is no problem now, (...) it is not good (...) so we have already spoiled the image of our own law (...). The problem is going to increase as well (...) they will start looking for more people to contaminate, so that is practically not good (..). It will not be a good thing to increase the number of men who have sex with other men, $(\ldots)$ because we are damaging our health every time. Opinion leader, youth leader 2 Quelimane It can't happen. Just imagine that I as a woman have sex with another [woman], where I am going to do the biological needs process? I am already violating, I am going to enter a part that you can't do, or I end up doing things that tomorrow will harm me. Opinion leader, community health activist Nampula

Since my childhood, my father and mother have said you have to marry and have children, build you[rself a] home. That is why I said they [women with women] don't match well because every woman dreams of children, dreams of getting married. If I date another woman, I can't. Opinion leader, youth leader Maputo

Whilst the expectation of marriage and offspring, instilled from childhood, featured prominently in the othering discourses about both groups, leaders distinguished between the groups to indicate the gravity of deviance for society. For sex workers, generally assumed to be female, marriage prospects were perceived to be slim but not impossible, and motherhood not an overt concern. The perceived inability of LGBTI people to take part in the collective responsibility of building the nation, however, was an abomination in the eyes of most leaders. A number of them expressed the desire for a reinstatement of articles 70 and 71 in criminal law, pointing at the need to recentre sexuality within marriage and with the opposite sex only. We also found that a considerable number of leaders, across the different strata of leadership that we interviewed, would personally wish to intervene by sensitising LGBTI people and sex workers in their community and offering them rehabilitation pathways to put an end to their "activities."

So in this sense it is not discrimination, but to prohibit that we do not have to do it this way. If you want to have sex you have to get married, as I was saying you have to get married, but it is not like that, that people may go 
out to practice sex on the street just like that, randomly. Opinion leader, neighbourhood secretary 2 Quelimane [In the church, homosexuals] (...) I think these are allowed, but they must be educated, they must be educated, they must be taught that the path they are following is not correct (...) Opinion leader, religious leader 2 Maputo

Both actions were deemed legitimate by those who proposed them, based on the normative expectations around male and female sexual behaviour which are in conflict with the changes made in country legislation. In the minds of the opinion leaders, the majority of them being male, representations of non-conforming genders and sexual orientations converged and were most often verbalised through the example of the man who is attracted to other men who automatically feels and acts as if he is a woman (through for example feminine gestures, preferences, and dress code).

A larger issue arose from the discussions on legislative change, whereby leaders displayed limited confidence in the law as an instrument for pursuing equality and non-discrimination in Mozambique. Current inequalities in class, race, ethnicity, political and religious affiliation, gender, and between geographical regions in Mozambique were provided as stark examples of the State's inability and unwillingness to mitigate these gaps despite well-crafted legislation. Whilst leaders who supported the opposition party tended to be more critical, systemic challenges in law enforcement capacity resonated across leadership strata and were believed to negatively influence community consciousness of the rule of law and its utility in enhancing equality and countering discrimination.

For example, the State supports through the laws and at some point the laws are not enforced, that is where things start to fail. The government has its policies in relation to these matters and they draft laws, then nobody complies with the laws and people end up feeling that they are discriminated against (...) For example, we have the police. If you are HIV positive and someone called you names, you could go to the police, the police already have this law but what happens is that at some point this has no weight, no weight and maybe also due to lack of financial capacity or ability or because of not wanting to get involved, people may at some point be discriminated against but do not bother to take the matter to the appropriate structures. Opinion leader, neighbourhood secretary 2 Maputo

\section{Discussion}

The study findings illustrate the complexities of integrating socially contentious rights obligations in domestic legislation. Interrogation and reconciliation of potential conflicts form a critical part of the adoption process, in which new moral ideals or standards first need to find their resonance before they can be absorbed by society. We observed how the legislative step of liberalising certain sexual rights and freedoms gained little traction with community leaders in three provincial capitals of Mozambique and remained unsupported by a concerted policy approach to address the conflicts between the advancement of LGBTI and sex workers rights and prevailing social norms.

Grappling with the underlying moral issues is as daunting as it is necessary (Feldblum, 1997). Around the world, the single act of decriminalising same-sex sexuality and sex work has never been transformative (Gauthier, 2011; Stoddard, 1997; Weitzer, 2018). One important prerequisite for change - a palpable legitimacy to pass such law-was not evident from our data. Our findings highlight some of the strong social prejudices that affected the validity of this reform for a cross-section of influential community members. Similar views with regard to same-sex sexuality were also found in a study among Mozambican parliament members (LAMBDA, 2018) and suggest that reservations exist, even at the highest level of governance, against fully supporting the implementation of the law and policy reforms. This may, in part, explain the protracted silence on this policy issue and the observed lack of decisiveness on the part of the government to further anchor LGBTI and sex workers rights in ordinary law since these first important strides were made (OCHCR, 2018). Another contributing factor may be found in the complex relationships between the State and its development partners (or donors) and with local civil society pressure groups, which has been the subject of study by other scholars (De Renzio \& Hanlon, 2007; Ilal et al., 2014; Obarrio, 2014; Pfeiffer, 2004). Our findings provide a sense of this complexity, by describing some of the dynamics within the power of influence in how the various laws and policies under study were conceived and omitted the step of interrogating and reconciling the potential resistance against these plans. Passages in laws that unequivocally shift longstanding norms need to be bolstered through an open debate in which the grounds for their legitimacy as well as the culture that sustains these norms can be explored (Stoddard, 1997). Avoidance to consult with and inform the public, including key leaders of the community, on the legislative changes places the onerous task of articulating and defending a "decriminalised" status on the civil society pressure groups and, within their own circles, on individual LGBTI and sex workers. And as our analysis showed, this task is already hindered at the base, whereby the sex worker associations conceal their true organisational identity to shun further attention, thus creating a vicious cycle in which their rights and voices remain unnoticed or frail, and rights violations can continue to occur without legal repercussions for the perpetrator (Tiyana Vavasate, 2019). 
The social constructs of the stigmas against LGBTI people and sex workers are deeply engrained in intersecting religious, sexual, gender, and cultural norms. Our findings pointed at a widely shared perception of the supreme authority of a religious rule of law over a man-made law, which sufficed in "legitimising" rehabilitative actions against both LGBTI people and sex workers through religious institutions or believers in their communities. Whilst religious beliefs were not used to block the reform-or even harshen the criminal law as witnessed elsewhere in the region (Cobb, 2014) - the study findings do shed light on the potency of these beliefs in overshadowing the principle of non-discrimination and in setting these particular individuals apart from the rest. There is a vast body of knowledge on how different forms of human disqualifications determine people's life chances and give rise to social inequalities (Braveman et al., 2011; Hatzenbuehler et al., 2013; Jordan, 1996; Link \& Phelan, 2001; Willen et al., 2017). Laws and policies are our mainstream instruments in countering these inequalities, but it is very hard "to get it right." What this and other studies demonstrate is that States do need to step into the arena where these problems manifest and are reproduced (Dani \& de Haan, 2008; Fineman \& Grear, 2013; MacIntosh, 2013). Such interventionist approaches were observed in the health and, to an extent, law enforcement sector in Mozambique with the support of international donors but failed to reach community members, such as religious and neighbourhood leaders, who are important influencers in this arena. Providing a platform for engagement, deliberation and interpretation on the rights obligations with leaders such as these will be critical to begin to shift some of the perceptions of LGBTI people and sex workers that contest the universality of rights (Bicchieri \& Mercier, 2014; Cislaghi $\&$ Heise, 2019; Gatens, 2004). Other scholars and experts have also reported on the necessity to invest in education and awareness-raising to dispel myths and misconceptions and break the cycle of discrimination and exclusion, as well as to strengthen the current legal framework for LGBTI people and sex workers (Ngale et al., 2019; OCHCR, 2018).

There remains the perhaps uneasy question of issue salience in the context of wider rights deprivations occurring in the communities these leaders are serving. In our study setting, leaders articulated rights from a frame of "essentials" (i.e. basic necessities, such as food, shelter, health, and employment) and not as an expression of autonomy. In this frame, there was an understanding for a sex worker's predicament to provide for her family, but not for her enjoyment of a progressive, independent lifestyle. This demarcation of rights along the lines of necessity and frivolity or morality and immorality has also been posited as the antagonism between the ideals of "traditional" social obligation and "modern" individualism in the present era (Boyd, 2013). In the absence of a felt need and validity of particular rights for
LGBTI people and sex workers, such as the right to sexual autonomy or the right to choose a partner, the new laws and policies are not likely to make a profound impact on the lives of LGBTI people and sex workers and on the social pressures that preclude the acceptance of their sexual rights in order to maintain moral normality.

\section{Policy Implications}

The findings confirm the limited function of the law in exercising authority on socially contentious issues, including sexuality and sexual rights. As a way forward, we propose a revision of the current community involvement strategy for health and an expanded ministerial policy response. A wider circulation and awareness of the country's laws and policies needs to be supported by carefully facilitated community dialogues and engagement of community leaders to start mediating the social processes that undercut the universality of rights and that justify the subjugation of LGBTI people and sex workers to rehabilitative practices at the risk of social exclusion and poor health outcomes. The observed consensus among opinion leaders on the need to counter discriminatory acts against both groups in their communities could provide an opening into these dialogues. In combination with the community involvement strategy, we suggest that current policy articulations extend beyond the health and law enforcement sectors and include the description of roles, responsibilities, and strategies towards the enforcement of the legal framework and the protection of LGBTI people and sex workers from discrimination by each of the following Ministries, based on their respective mandates: the Ministry of State Administration and Public Service, the Ministry of Gender, Children and Social Affairs, and (in addition to the guidelines for Police officers) the Ministry of Justice and Constitutional and Religious Affairs. The need for local administrators to be more informed and supportive of government law and policy became apparent through this study and should be one of the first steps in strengthening the accountability of multiple ministries towards policy implementation, including its endorsement from the higher political level, followed by the strengthening of local government support structures that are seen to safeguard the health and wellbeing of LGBTI people and sex workers in the community.

\section{Limitations}

The study faced a number of limitations. First, it proved challenging to recruit within the select group of individuals who had been directly involved in the reform of the labour law and/ or penal code, some of whom currently occupy high political positions. Interview appointments were repeatedly rescheduled as a result of highly demanding agendas, with further pressures 
arising from key events that coincided with the study period, among which the emergency situation in Central Mozambique and the Presidential elections. We thus had to reconstruct the reform processes based on a less ideal composition of study participants from within and outside of the select group, which affects the validity of our findings. Participants from outside of the select group were individuals that were either consulted at any stage during the reforms or had been close observants of these processes. In order to identify and recruit these individuals, we intensified our snowball sampling and extended the study period. Secondly, our sample of opinion leaders is not representative of the diversity of opinions on the law, normative behaviour and on LGBTI people and sex workers that are present in Mozambique. Our aim was to explore these opinions across geographical and ethnic divides and, within cities, across diverse socio-economic and leadership strata and contribute to the, up to date, scant country data on this issue and to utilise the reforms as a reference point for this investigation. The study also provides further depth and nuance to the quantitative survey findings on tolerance towards same-sex sexuality in which Mozambique stood out more favourably (Dulani et al., 2016). Our next step is to investigate the perspectives of LGBTI people and sex workers on the legislative changes, and whether and how this may be of influence on their social position. Whilst doing so, we hope to get a better understanding of the LGBTI community in its full diversity, as the key informants and opinion leaders in our study concentrated their narratives almost exclusively on men who have sex with men and women who have sex with women.

\section{Conclusion}

As international rights obligations find their codification in domestic laws and policies, there needs to be a real engagement with the public and with the underlying moral issues that may hinder their acceptance. The case of Mozambique illustrates the uphill battle for legal norms that remain distant from the public, due to the lack of popularisation in the society and their tension with social norms, as relayed by opinion leaders residing in different parts of the country. This places the onerous task of claiming a legitimate social standing on civil society pressure groups and individual LGBTI and sex workers, and attenuates the country's commitment to the universality of rights. The exemplary step of breaking away from an inherited law which classified certain sexual activities as crimes now needs to be supported by interventions which combat the stigma and discrimination against LGBTI people and sex workers and encourage their social inclusion and acceptance in Mozambique.

Supplementary Information The online version contains supplementary material available at https://doi.org/10.1007/s13178-021-00554-1.
Acknowledgements This research forms part of a larger projecton Strengthening Legal and Policy Environments for reducing HIV Risk andImproving Sexual and Reproductive Health for Young Key Populations in SouthernAfrica which is being carried out in Angola, Madagascar, Mozambique, Zambia andZimbabwe. The authors would like to thank colleagues involved in this largerproject and, in particular, Jane Freedman and Tamaryn Crankshaw for theircomments on an earlier version of this article.

Author Contributions CA conceived the study, acquired funding, oversaw data collection, analysed the data and wrote the manuscript. KM codesigned the study, adapting itto the Mozambican context, conducted and supervised field work, analysed data, andrevised the manuscript. $\mathrm{VM}$ and RC participated in the study design adaptation,conducted data collection, analysed data, and reviewed manuscript drafts. NP conceived the study, acquired funding, revised the manuscript and wasin charge of the overall direction of the research project. All authors read and approved the final manuscript.

Funding This study was funded by the Ministry of ForeignAffairs of the Kingdom of The Netherlands as part of their regional HIV/AIDSand SRHR programme in Southern Africa (Grant number: 00091626). The funder hadno role in the design of the study, data collection and analysis, the decisionto publish, or preparation of the manuscript. The content is solely theresponsibility of the authors and does not necessarily represent the officialviews of the funder.

Data and/or Code Availability The research data forthis study has not been deposited in a public repository as these datasetsconcern qualitative interviewtranscripts whichhave not been appropriately anonymised to enablesharing. Sharing these datasetscould potentially breach the informed consent agreement that was negotiatedwith the study participants in the collection of the qualitative data. Inthe illustrative quotations we have ensured anonymity but this cannot beguaranteed within the primary transcripts.

\section{Declarations}

Ethical Approval This study was performed in line with the principles of the Declaration of Helsinki. Approval was granted by the Ethics Committee of Biomedical Research Ethics Committees of the University of KwaZulu-Natal in South Africa (ref. (BE502/17)) and the Institutional Bioethics Committee of the Eduardo Mondlane University's Faculty of Medicine and Maputo Central Hospital in Mozambique (ref. 136/GMS/002/2018). In addition, Ministry of Health administrative approval, provincial health directorate administrative approvals in Sofala and Nampula provinces, and and municipal approvals were obtained from all three study sites to conduct the study and enable the researchers' entry into the sampled neighbourhoods.

Informed Consent Written informed consent was obtained from all individual participants included in the study.

Conflicts of interest The authors have no conflicts of interest todeclare that are relevant to the content of this article.

Open Access This article is licensed under a Creative Commons Attribution 4.0 International License, which permits use, sharing, adaptation, distribution and reproduction in any medium or format, as long as you give appropriate credit to the original author(s) and the source, provide a link to the Creative Commons licence, and indicate if changes were made. The images or other third party material in this article are included in the article's Creative Commons licence, unless indicated 
otherwise in a credit line to the material. If material is not included in the article's Creative Commons licence and your intended use is not permitted by statutory regulation or exceeds the permitted use, you will need to obtain permission directly from the copyright holder. To view a copy of this licence, visit http://creativecommons.org/licenses/by/4.0/.

\section{References}

Altman, D. (2002). Global sex. University of Chicago Press.

Baier, M. (2016). Social and legal norms: Towards a socio-legal understanding of normativity. Routledge.

Benoit, C., Jansson, S. M., Smith, M., \& Flagg, J. (2018). Prostitution stigma and its effect on the working conditions, personal lives, and health of sex workers. The Journal of Sex Research, 55(4-5), 457-471.

Bicchieri, C., \& Mercier, H. (2014). Norms and beliefs: How change occurs. Springer.

Boyd, L. (2013). The problem with freedom: Homosexuality and human rights in Uganda. Anthropological Quarterly, 697-724.

Braveman, P. A., Kumanyika, S., Fielding, J., LaVeist, T., Borrell, L. N., Manderscheid, R., \& Troutman, A. (2011). Health disparities and health equity: The issue is justice. American Journal of Public Health, 101(S1), S149-S155.

Centro do Direitos Humanos. (2017). Relatório do estudo sobre a situação económica, social e política das pessoas LGBT nas cidades de Maputo, Beira e Nampula. Centro do Direitos Humanos \& LAMBDA: Maputo.

Chissano, J. (2014). An open letter to Africa's leaders-Joaquim Chissano, former President of Mozambique [Press release].

Cislaghi, B., \& Heise, L. (2019). Using social norms theory for health promotion in low-income countries. Health Promotion International, 34(3), 616-623.

CNCS. (2015). Plano Estratégico Nacional de Resposta ao HIV e SIDA 2015-2019 (PEN IV). Maputo.

Cobb, N. (2014). Rethinking the "World Polity” perspective on global sodomy Law reform. Springer.

Constitution of the Republic of Mozambique. (2004). Constituição da República.

Da Costa Santos, G. G., \& Waites, M. (2019). Comparative colonialisms for queer analysis: Comparing British and Portuguese colonial legacies for same-sex sexualities and gender diversity in Africa-Setting a transnational research agenda. International Review of Sociology, 29(2), 297-326.

De Renzio, P., Hanlon, J. (2007). Contested sovereignty in Mozambique: The dilemmas of aid dependence. GEG Working Paper, No. 2007/25. Oxford:, University of Oxford, Global Economic Governance Programme.

Dani, A. A., \& de Haan, A. (2008). Inclusive states: Social policy and structural inequalities. New Frontiers of Social Policy. Washington, DC: World Bank. https://openknowledge.worldbank.org/ handle/10986/6409

De Lisio, A., Hubbard, P., \& Silk, M. (2019). Economies of (alleged) deviance: Sex work and the sport mega-event. Sexuality Research and Social Policy, 16(2), 179-189.

Decker, M. R., Crago, A.-L., Chu, S. K., Sherman, S. G., Seshu, M. S., Buthelezi, K., et al. (2015). Human rights violations against sex workers: Burden and effect on HIV. The Lancet, 385(9963), 186-199.

Do Rosário Augusto, Â., Young, P. W., Horth, R. Z., Inguane, C., Sathane, I., Ngale, K., , et al. (2016). High burden of HIV infection and risk behaviors among female sex workers in three main Urban areas of Mozambique. AIDS and Behavior, 20(4), 799.
Drabble, L. A., Wootton, A. R., Veldhuis, C. B., Perry, E., Riggle, E. D., Trocki, K. F., \& Hughes, T. L. (2020). It's complicated: The impact of marriage legalization among sexual minority women and gender diverse individuals in the United States. Psychology of Sexual Orientation and Gender Diversity (https://doi.org/10.1037/ sgd0000375).

Dulani, B., Sambo, G., \& Dionne, K. Y. (2016). Good neighbours? African express high levels of tolerance for many but not for all. Afrobarometer Dispatch, (74), 1-27.

Family Law. (2004). Lei n. ${ }^{\circ}$ 10/2004. Lei da Família da República de Moçambique.

Ellingson, S., \& Green, M. C. (Eds.). (2002). Religion and sexuality in cross-cultural perspective. Routledge.

Feldblum, C. R. (1997). The moral rhetoric of legislation. New York University Law Review, 72, 992.

Fineman, M. A., \& Grear, A. (2013). Equality, autonomy, and the vulnerable subject in law and politics. In Vulnerability: Reflections on a New Ethical Foundation for Law and Politics, edited by Fineman, M \& Grear, A. Abingdon: Routledge.

Freeman, E., \& Coast, E. (2019). Conscientious objection to abortion: Zambian healthcare practitioners' beliefs and practices. Social Science \& Medicine, 221, 106-114.

Gamariel, F., Isaakidis, P., Tarquino, I. A. P., Beirão, J. C., O'Connell, L., Mulieca, N., et al. (2020). Access to health services for men who have sex with men and transgender women in Beira, Mozambique: A qualitative study. PLOS ONE, 15(1), e0228307.

Gatens, M. (2004). Can human rights accommodate women's rights? Towards an embodied account of social norms, social meaning, and cultural change. Contemporary Political Theory, 3(3), $275-299$.

Gauthier, J. (2011). Prostitution, sexual autonomy, and sex discrimination. Hypatia, 26(1), 166-186.

Gerber, P. (2014). Living a life of crime: The ongoing criminalisation of homosexuality within the Commonwealth. Alternative Law Journal, 39(2), 78-83.

Gupta, A. (2008). This alien legacy: The origins of" sodomy" laws in British colonialism. Human Rights Watch.

Hafner-Burton, E. M., \& Tsutsui, K. (2005). Human rights in a globalizing world: The paradox of empty promises. American Journal of Sociology, 110(5), 1373-1411.

Hatzenbuehler, M. L., Phelan, J. C., \& Link, B. G. (2013). Stigma as a fundamental cause of population health inequalities. American Journal of Public Health, 103(5), 813-821.

Hendriks, S., \& Rácz, S. (2016). Sex work and violence in Mozambique. Needs assessment report. Amsterdam.

Herek, G. M. (2011). Anti-equality marriage amendments and sexual stigma. Journal of Social Issues, 67(2), 413-426.

Hough, N. A. (2004). Sodomy and prostitution: laws protecting the fabric of society. Pierce Law Review, 3, 101.

Howell, P. (2000). Prostitution and racialised sexuality: the regulation of prostitution in Britain and the British Empire before the Contagious Diseases Acts. Environment and Planning D: Society and Space, 18(3), 321-339.

Huberman, A. M., \& Miles, M. B. (1994). Data management and analysis methods. In N. K. Denzin \& Y. S. Lincoln (Eds.), Handbook of Qualitative Research (pp. 428-444). Sage Publications Inc.

Human Rights Council. (2011). Report of the working group on the Universal Periodic Review Mozambique.

Human Rights Council. (2016). Report of the working group on the Universal Periodic Review Mozambique. Retrieved from https:// www.ohchr.org/EN/HRBodies/UPR/Pages/MZindex.aspx

Ilal, A., Kleibl, T., \& Munck, R. (2014). Interrogating civil society: A view from Mozambique. DSA Ireland working paper 2. 
Instituto Nacional de Estatística. (2019). IV Recenseamento Geral da População e Habitação, 2017 Resultados Definitivos - Moçambique. Maputo.

Jordan, B. (1996). A theory of poverty and social exclusion. Polity Press.

Knauer, N. J. (2012). Legal consciousness and LGBT research: The role of the law in the everyday lives of LGBT individuals. Journal of Homosexuality, 59(5), 748-756.

Labour Law. (2007). Lei n. ${ }^{\circ}$ 23/2007. Lei do Trabalho da República de Moçambique.

LAMBDA. (2018). Estudo Conhecimento, Atitudes e Práticas nos deputados em relação a pessoas LGBT em Moçambique. (unpublished report) LAMBDA: Maputo.

Law on Human Trafficking. (2008). Lei n. ${ }^{\circ} 6 / 2008$. Lei do Tráfico de Pessoas da República de Moçambique.

Law on the Protection of people, employees and job candidates living with HIV and AIDS. (2014). Lei n. ${ }^{\circ}$ 19/2014: Lei de Protecção da Pessoa, do Trabalhador e do Candidato a Emprego Vivendo com HIV e SIDA da República de Moçambique.

Law on the Promotion and Protection of the Rights of the Child. (2008). Lei n. ${ }^{\circ} 7 / 2008$. Lei de Promoção e Protecção dos Direitos da Criança da República de Moçambique.

Law on Domestic Violence perpetrated against Women. (2009). Lei n. ${ }^{\circ} 29 / 2009$. Lei sobre a violência doméstica praticade contra a mulher da República de Moçambique.

Levy, J. (2014). Criminalising the purchase of sex: Lessons from Sweden. Routledge.

Link, B. G., \& Phelan, J. C. (2001). Conceptualizing stigma. Annual review of. Sociology, 27(1), 363-385.

Lorber, J. (2018). The Social Construction of Gender (2nd ed.). Routledge.

MacIntosh, C. (2013). The role of law in ameliorating global inequalities in Indigenous peoples' health. The Journal of Law, Medicine \& Ethics, 41(1), 74-88.

Mendos, L. R. (2019). State-sponsored homophobia (Thirteenth ed.). Geneva: International Lesbian, Gay, Bisexual, Trans and Intersex Association (ILGA).

Mgbako, C. (2016). To live freely in this world: Sex worker activism in Africa. NYU Press.

Miller, A. M., Kismödi, E., Cottingham, J., \& Gruskin, S. (2015). Sexual rights as human rights: a guide to authoritative sources and principles for applying human rights to sexuality and sexual health. Reproductive Health Matters, 23(46), 16-30.

Ministry of Health. (2015). Directriz para Integração dos Serviços de Prevenção, Cuidados e Tratamento do HIV e SIDA para População Chave no sector da Saúdemédica pnc ITS/HIV/SIDA. Maputo.

Ministry of Home Affairs, Pathfinder, \& Bridging the Gaps. (2018). Manual do Formador. Attendimento as populacoes-chave. Ministry of Home Affairs: Maputo.

Nalá, R., Cummings, B., Horth, R., Inguane, C., Benedetti, M., Chissano, M., et al. (2015). Men who have sex with men in Mozambique: identifying a hidden population at high-risk for HIV. AIDS and Behavior, 19(2), 393.

Namwase, S. (2017). Culture versus Homosexuality: Can a right 'from' culture be claimed in Ugandan Courts? Pretoria University Law Press.

Ngale, K., Cummings, B., \& Horth, R. (2019). Unseen, unheard and unprotected: prevalence and correlates of violence among female sex workers in Mozambique. Culture, Health \& Sexuality, 21(8), 898-913.

Obarrio, J. (2014). The spirit of the laws in Mozambique. University of Chicago Press.

OCHCR. (2018). End of mission UN independent SOGI expert visit to Mozambique [Press release]. Office of the High Commissioner for
Human Rights Retrieved from: https://www.ohchr.org/EN/NewsE vents/Pages/DisplayNews.aspx?NewsID $=24002 \&$ LangID $=\mathrm{E}$

Pfeiffer, J. (2004). Civil society, NGOs, and the holy spirit in Mozambique. Human Organisation, 63(3), 359-372.

Poku, N. K., Esom, K., \& Armstrong, R. (2017). Sustainable development and the struggle for LGBTI social inclusion in Africa: Opportunities for accelerating change. Development in Practice, 27(4), 432-443.

Poku, N. K., \& Sundewall, J. (2018). Political responsibility and global health. Third World Quarterly, 39(3), 471-486.

Penal Code. (2014). Lei n. ${ }^{\circ}$ 35/2014. Código Penal da República de Moçambique.

Portuguese Penal Code. (1886). Código Penal Português, Ordained by the Decree 39, 688, 5th June 1954. Coimbra.

Richardson, D. (2004). Locating sexualities: From here to normality. Sexualities, 7(4), 391-411.

Rublack, U. (Ed.). (2017). The Oxford handbook of the Protestant reformations. Oxford University Press.

Sable, S. M. (2010). A prohibition on antisodomy laws through regional customary international law. Law \& Sexuality: Rev. Lesbian, Gay, Bisexual \& Transgender Legal Issues, 19, 95.

Scorgie, F., Vasey, K., Harper, E., Richter, M., Nare, P., Maseko, S., \& Chersich, M. F. (2013). Human rights abuses and collective resilience among sex workers in four African countries: a qualitative study. Globalization and Health, 9(1), 33.

Smith, M., \& Mac, J. (2018). Revolting prostitutes: The fight for sex workers' rights. Verso Books.

Stoddard, T. B. (1997). Bleeding heart: Reflections on using the law to make social change. New York University Law Review, 72, 967.

Stuntz, W. (2000). Self-Defeating Crimes. Virginia Law Review, 86, $1871-1882$.

Tamale, S. (2014). Exploring the contours of African sexualities: Religion, law and power. African Human Rights Law Journal, 14(1), $150-177$.

Tiyana Vavasate. (2019). CEDAW shadow report: Submission by Tiyane Vavasate Association to the Committee on the Elimination of All Forms of Discrimination Against Women in Mozambique. CEDAW 73 ${ }^{\text {rd }}$ session 2019.

Tsimitri, P., Michailidis, A., Partalidou, M., \& Kountios, G. (2015). The real rural influentials: Behavioural dimensions of perceived leadership which influence rural people. Procedia Economics and Finance, 33, 211-218.

Universal Declaration of Human Rights. (1948), GA Res. 217A (III), UN GAOR, 3d Session 1948.

Vanwesenbeeck, I. (2017). Sex work criminalization is barking up the wrong tree. Archives of Sexual Behaviour, 46(6), 1631-1640.

Weimann, G., Tustin, D. H., Van Vuuren, D., \& Joubert, J. P. R. (2007). Looking for opinion leaders: Traditional vs. modern measures in traditional societies. International Journal of Public Opinion Research, 19(2), 173-190.

Weitzer, R. (2018). Resistance to sex work stigma. Sexualities, 21(5-6), $717-729$

Willen, S. S., Knipper, M., Abadía-Barrero, C. E., \& Davidovitch, N. (2017). Syndemic vulnerability and the right to health. The Lancet, 389(10072), 964-977.

Wilson, R. F. (2012). The calculus of accommodation: contraception, abortion, same-sex marriage, and other clashes between religion and the state. Boston College Law Review, 53, 1417.

Yep, G. A. (2003). The violence of heteronormativity in communication studies: Notes on injury, healing, and queer world-making. Journal of Homosexuality, 45(2-4), 11-59.

Publisher's Note Springer Nature remains neutral with regard to jurisdictional claims in published maps and institutional affiliations. 